Michael D. Minton MD, Joseph A. Stirt MD, Robert F. Bedford MD

\title{
Serum potassium following succinyl- choline in patients with brain tumours
}

Serum potassium levels were measured in 15 patients with brain tumours between $3-7 \mathrm{~cm}$ diameter, during thiopentonel70 per cent $\mathrm{N}_{2} \mathrm{O}$ in $\mathrm{O}_{2}$ anaesthesia, with mask ventilation controlled to maintain a constant end-tidal $\mathrm{CO}_{2}$ concentration. Potassium levels were determined one minute before and one and ten minutes after administration of succinylcholine $1.0 \mathrm{mg} \cdot \mathrm{kg}^{-1} \mathrm{~N}$. No statistically significant increase in serum potassium occurred following succinylcholine, nor were there any ECG changes associated with succinylcholine administration. Use of succinylcholine in patients with brain tumours does not appear to cause elevation of serum potassium levels or ECG changes.

Hyperkalaemia following succinylcholine, usually with accompanying electrocardiographic changes, has been described in a variety of central nervous system dysfunctions. Thus, patients with encephalitis, ${ }^{1}$ tetanus, ${ }^{2}$ cerebral haematoma following closed head injury, ${ }^{3}$ and ruptured cerebral aneurysm $^{4}$ have been reported to have large acute increases in serum potassium levels after succinylcholine, even though most of these patients were not hemiplegic or paraplegic.

More recent studies ${ }^{5,6}$ have emphasized that

\section{Key words}

BRAIN: intracranial tumours; IONS: potassium, hyperkalemia; NEUROMUSCULAR RELAXANTS: succinylcholine.

From the Department of Anaesthesiology, University of Virginia Medical Center, Charlottesville, VA.

Address correspondence to: Dr. Joseph A. Stirt, Department of Anesthesiology, Box 238, University of Virginia Medical Center, Charlottesville, VA 22908, U.S.A. hyperkalaemia without evidence of EKG changes may occur in patients with intracranial pathology, and this led us to wonder whether the phenomenon of "transient acute silent hyperkalaemia" occurred in a significant proportion of patients with brain tumours, either with or without evidence of upper motor nerve dysfunction. For this reason, we prospectively evaluated the effects of succinylcholine on serum potassium levels and EKG patterns in patients with brain tumours, most of whom had evidence of upper motor neuron lesions.

\section{Methods}

The study protocol was approved by the University Human Investigation Committee and informed consent was obtained. The subjects were 15 consecutive patients scheduled for elective craniotomy and tumour resection. Patients ranged in age from 44-75 years and were free of significant concurrent cardiopulmonary disease. Preoperative computerized tomography (CT) scans revealed supratentorial tumours of $3-7 \mathrm{~cm}$ diameter in all patients. The preoperative neurological status of all patients is detailed in Table I.

On arrival in the operating suite, peripheral venous cannulae, a 20-gauge radial arterial catheter, and a subarachnoid pressure bolt were placed under local anaesthesia. Intracranial pressure (ICP) and mean arterial blood pressure (BP) were transduced continuously and recorded, with the zero reference point at the external auditory meatus. A standard lead II EKG was monitored.

With the patients in the supine $15^{\circ}$ head-up position, general anaesthesia was induced with thiopentone, $6 \mathrm{mg} \cdot \mathrm{kg}^{-1} \mathrm{IV}$, and 70 per cent nitrous oxide in oxygen. Ventilation was carefully controlled by mask throughout the study period to maintain a constant end-tidal $\mathrm{CO}_{2}$ concentration (Hewlett-Packard Model 47310-A capnometer). 
TABLE I Preoperative neurological status and awake intracranial pressure (ICP) in 15 patients with brain tumours

\begin{tabular}{|c|c|c|}
\hline Patient & Neurological status & $\begin{array}{l}/ C P \\
(m m H g)\end{array}$ \\
\hline 1 & Normal & 10 \\
\hline 2 & Left-sided weakness - 1 week & 10 \\
\hline 3 & Normal & 15 \\
\hline 4 & Nomal & 15 \\
\hline 5 & Mild left-sided weakness - 4 months & 20 \\
\hline 6 & Left hemiparesis - 1 week & 15 \\
\hline 7 & Right hemiparesis - 1 month & 17 \\
\hline 8 & Right hemiparesis -2 days & 17 \\
\hline 9 & Normal & 15 \\
\hline 10 & Normal & 15 \\
\hline 11 & Right-sided weakness - 3 weeks & 15 \\
\hline 12 & Normal & 12 \\
\hline 13 & Left hemiparesis - 1 month & 15 \\
\hline 14 & Left hemiparesis - 2 weeks & 25 \\
\hline 15 & Left hemiparesis - 1 month & 10 \\
\hline
\end{tabular}

A $5 \mathrm{ml}$ arterial blood sample for serum potassium level and blood gas analysis was obtained one minute before a. bolus of succinylcholine, $1 \mathrm{mg}$. $\mathrm{kg}^{-1} \mathrm{IV}$, was administered over five seconds. Less than $0.1 \mathrm{ml}$ of aqueous heparin solution was used as an anticoagulant in each $5 \mathrm{ml}$ sample. Serum potassium was determined using an ion-selective electrode technique (NOVA 1 Sodium/Potassium Analyzer, Nova Biomedical, Newton, MA 02164). Repeat blood samples were obtained one and ten minutes after succinylcholine administration and also were analyzed for serum potassium level and arterial blood gas tensions. Changes in serum potassium, arterial $\mathrm{PCO}_{2}$ and $\mathrm{pH}, \mathrm{ICP}$, and $\mathrm{BP}$ were compared using Student's t-test for paired data. $\mathrm{p}<0.05$ was regarded as significant.

\section{Results}

The preoperative neurological status and ICP of each patient before anaesthesia are listed in Table I. Table II summarizes our findings for serum potassium, arterial $\mathrm{PCO}_{2}$, and arterial $\mathrm{pH}$ determinations made one minute before and one and ten minutes after succinylcholine, $1 \mathrm{mg} \cdot \mathbf{k g}^{-1}$ IV. No statistically significant change occurred in any of the three variables after succinylcholine and the ECG complex, monitored for ten minutes, remained unchanged in all patients. ICP increased significantly following succinylcholine, from $15 \pm 4 \mathrm{mmHg}$ to $21 \pm 5 \mathrm{mmHg}$ (mean $\pm \mathrm{SD}$ ), and $\mathrm{BP}$ was unchanged $(85 \pm 14 \mathrm{mmHg}$ before succinylcholine,
$82 \pm 12 \mathrm{mmHg}$ (mean $\pm \mathrm{SD}$ ) after succinylcholine).

The largest increse in serum potassium in any individual was $0.4 \mathrm{mEq} \cdot \mathrm{L}^{-1}$. No differences in serum potassium values before and after succinylcholine could be attributed to the presence or absence of preoperative neurological deficits or elevated ICP.

\section{Discussion}

The cause of succinylcholine-induced hyperkalaemia in some central nervous system disturbances remains obscure. In certain disorders, such as spinal cord injuries resulting in paraplegia, ${ }^{7}$ cerebrovascular accidents accompanied by hemiplegia, ${ }^{8}$ or quadriplegia following brain tumour resection, ${ }^{9}$ the cause of succinylcholine-induced hyperkalaemia seems well characteized. In these conditions, the mechanism appears to be increased chemosensitivity of the muscle membrane following functional denervation due to the development of receptor sites in extrajunctional areas. ${ }^{10}$

In other conditions, such as encephalitis, ${ }^{1}$ tetanus, ${ }^{2}$ closed head injury, ${ }^{3}$ and ruptured cerebral aneurysm, ${ }^{4,6}$ the mechanism is not understood. Prolonged immobility resulting in disuse atrophy with subsequent increased chemosensitivity to succinylcholine has been suggested as a possible cause of succinylcholine-induced hyperkalaemia in some of these conditions, ${ }^{11}$ but no study documenting such changes has ever been reported in humans. In addition, many patients with, for example, ruptured cerebral aneurysms who developed succinylcholineinduced hyperkalaemia had no evidence of hemiplegia or paraplegia nor was there any evidence of weight loss, muscle atrophy, or immobility for more than a few days. ${ }^{5}$ In eight of the nine patients

TABLE II Serum potassium $\left(\mathrm{K}^{+}\right)$, arterial $\mathrm{PCO}_{2}$ and $\mathrm{pH}$ before and after succinylcholine (Sch) $1.0 \mathrm{mg} \cdot \mathrm{kg}^{-1}$ in 15 patients with brain tumours

\begin{tabular}{lccc}
\hline & $\begin{array}{l}\text { I minute } \\
\text { before Sch }\end{array}$ & $\begin{array}{l}\text { I minute } \\
\text { after Sch }\end{array}$ & $\begin{array}{l}\text { 10 minutes } \\
\text { after Sch }\end{array}$ \\
\hline $\mathrm{K}^{+}\left(\mathrm{mEq} \cdot \mathrm{L}^{-1}\right)$ & $3.5 \pm 0.4$ & $3.5 \pm 0.4$ & $3.5 \pm 0.4$ \\
$\mathrm{PaCO}_{2}$ & $37.7 \pm 5.4$ & $38.0 \pm 5.4$ & $38.0 \pm 7.4$ \\
$\mathrm{pH}$ & $7.43 \pm 0.04$ & $7.43 \pm 0.04$ & $7.42 \pm 0.04$
\end{tabular}

All values mean $\pm \mathrm{SD}$.

No significant $(\mathrm{p}<0.05)$ differences in any of the values measured following succinylcholine. 
in our study with preoperative neurological deficits, the duration of the deficits was one month or less. Whether a longer duration would lead to a hyperkalaemic response to succinylcholine is uncertain, but in the one patient in our study population with a prolonged (four months) deficit, no increase in serum potassium occurred following succinylcholine.

Not all upper motor neuron lesions appear to be associated with hyperkalaemia after succinylcholine. A recent study ${ }^{12}$ measured plasma potassium in 36 children with cerebral palsy who were either hemiplegic or quadraplegic, and found no significant change in plasma potassium following succinylcholine, $2 \mathrm{mg} \cdot \mathrm{kg}^{-1} \mathrm{IV}$. The highest individual potassium rise was $0.4 \mathrm{mEq} \cdot \mathrm{L}^{-1}$, the same as the largest increase we observed in our 15 patients with brain tumours. The apparent safety of succinylcholine in these patients with chronic paralysis due to cerebral palsy contradicts the conventional wisdom that: "Succinylcholine should be avoided in paraplegic patients except during the immediate post-injury period." 13

The appropriate use of succinylcholine in patients with brain tumours is thus controversial. Although neuroanaesthetists have used succinylcholine for many years in these patients, one study ${ }^{5}$ has noted the occurrence of acute hyperkalameia (potassium increase from 3.7 to $8.4 \mathrm{mEq} \cdot \mathrm{L}^{-1}$ one minute following succinylcholine, $80 \mathrm{mg}$ IV) in a patient with a brain tumour and hemiplegia of six months duration. No ECG changes accompanied the potassium increase. However, four other patients with brain tumours and hemiplegia in that study had no significant increase in serum potassium values following succinylcholine. These authors advised "careful use of succinylcholine" in such patients.

The insignificant changes in serum potassium following succinylcholine in our 15 patients are similar to those seen in normal patients after succinylcholine. ${ }^{14-16}$ The relatively unchanged values of arterial $\mathrm{PCO}_{2}$ and $\mathrm{pH}$ at the time potassium values were obtained indicates that changes in acid-base status did not affect potassium levels. Specifically, there was no evidence of hyperventilation-induced respiratory alkalosis which might have caused intracellular potassium influx and lowered serum potassium following succinylcholine.

We measured potassium levels one minute after succinylcholine administration, a time at which peak increases in potassium have been reported in patients with central nervous system lesions who have become hyperkalaemic following succinylcholine. ${ }^{6}$ We believe that the absence of change in serum potassium values ten minutes after succinylcholine rules out the possibility of our missing a delayed episode of hyperkalaemia, since full recovery from paralysis occurred within ten minutes in all 15 patients.

In summary, we studied the effects of succinylcholine $1 \mathrm{mg} \cdot \mathrm{kg}^{-1}$ on serum potassium levels in patients with brain tumours and found no potassium increases or ECG changes in any of these patients. We conclude that hyperkalaemia following succinylcholine would appear unlikely in patients with brain tumours with or without accompanying motor nerve dysfunction, and we believe that succinylcholine should not be withheld for this reason when its use is indicated.

\section{References}

1 Cowgill DB, Mostella LA, Shapiro HM. Encephalitis and a hyperkalemic response to succinylcholine. Anesthesiology 1974; 40: 409-11.

2 Roth $F$, Wüthrich $H$. The clinical importance of hyperkalaemia following suxamethonium administration. Br J Anaesth 1969; 41: 311-6.

3 Stevenson $P H$, Birch AA. Succinylcholine-induced hyperkalemia in a patient with a closed head injury. Anesthesiology 1979; 51: 89-90.

4 Thomas ET. Circulatory collapse following succinylcholine: report of a case. Anesth Analg 1969; 48: 333-7.

5 Iwatsuki N, Akaishi T, Amaha K. Upper-motor neuron lesion and succinylcholine-induced hyperkalemia. Masui 1980; 29: 1509-13.

6 Iwatsuki $N$, Kuroda N, Amaha $K$, Iwatsuki $K$. Succinylcholine-induced hyperkalemia in patients with ruptured cerebral aneurysms. Anesthesiology 1980; 53: 64-7.

7 Cooperman $L H$. Succinylcholine-induced hyperkalemia in neuromuscular disease. JAMA 1970; 213: $1867-71$.

8 Cooperman LH, Strobel GE Jr, Kennell EM. Massive hyperkalemia after administration of succinylcholine. Anesthesiology 1970; 32: 161-4.

9 Smith $R B$, Grenvik A. Cardiac arrest following succinylcholine in patients with central nervous system injuries. Anesthesiology 1970; 33: 558-60. 
10 Gronert GA, Theye RA. Pathophysiology of hyperkalemia induced by succinylcholine. Anesthesiology 1975; 43: 89-99.

11 Groner GA, Theye RA. Effect of succinylcholine on skeletal muscle with immobilization atrophy. Anesthesiology 1974; 40: 268-71.

12 Dierdorf SF, MCNiece WL, Rao CC et al. Effects of succinylcholine on plasma potassium in children with cerebral palsy. Anesthesiology 1985; 62: 8890.

13 Azar I. The response of patients with neuromuscular disorders to muscle relaxants: A review. Anesthesiology 1984; 61: 173-87.

14 List WF. Serum potassium changes during induction of anaesthesia. Br. J. Anaesth 1967; 39: 480-4.

15 Stoelting $R K$, Peterson $C$. Adverse effects of increased succinylcholine dose following d-tubocurarine pretreatment. Anesth Analg 1975; 54: 282-8.

16 Fahmy NR, Malek NS, Lappas DG. Diazepam prevents some adverse effects of succinylcholine. Clin Pharmacol Ther 1979; 26: 395-8.

\section{Résumé}

Chez 15 patients présentant des tumeurs cérébrales de $3-7 \mathrm{~cm}$ de diamètre, le potassium sérique a été mesuré lors d' une anesthésie avec le thiopentone/70 pour cent de protoxyde d'azote et oxygène en normocarbie utilisant une ventilation contrôlée au masque. Le potassium sérique a été déterminé une minute avant et une et dix minutes après l'administration de la succinylcholine $1 \mathrm{mg} \cdot \mathrm{kg}^{-1}$ en injection intraveineuse. Aucune augmentation statistiquement significative du potassium sérique $n$ 'est survenue après succinylcholine et aucun changement de l'ECG ne fut associé à l'administration de succinylcholine. L'utilisation de la succinylcholine chez les patients présentant des tumeurs cérébrales n'apparaît pas comme étant la cause d'une élévation du potassium sérique ni des changements à l'ECG. 